\title{
Omega-3 Fatty Acid Concentration in Purslane (Portulaca oleraceae) is Altered by Photosynthetic Photon Flux
}

\author{
Usha R. Palaniswamy, ${ }^{1}$ Richard J. McAvoy, ${ }^{2}$ and Bernard B. Bible ${ }^{2}$ \\ School of Allied Health/Asian American Studies Institute, University of Connecticut, Storrs, CT 06269-2101
}

ADDITIONAL INDEX WORDS. essential fatty acids, $\alpha$-linolenic acid, irradiance, photosynthetic light duration, growth

\begin{abstract}
Purslane (Portulaca oleracea L.) is an excellent source of the essential fatty acid $\alpha$-linolenic acid (LNA) but little is known of the effects of cultural conditions on LNA concentration. Purslane seedlings were grown under an instantaneous photosynthetic photon flux $[P P F(400$ to $700 \mathrm{~nm})]$ of 299 or $455 \mu \mathrm{mol} \cdot \mathrm{m}^{-2} \cdot \mathrm{s}^{-1}$ for a daily duration of either $8,12,16$, or $20 \mathrm{hours}$. Thus, plants were exposed to a daily $P P F$ of $8.6,12.9,17.2$, or $21.5 \mathrm{~mol} \cdot \mathrm{m}^{-2} \cdot \mathrm{d}^{-1}$ in the low $P P F$ treatment $\left(299 \mu \mathrm{mol}^{-2} \cdot \mathrm{s}^{-1}\right)$ and 13.1, 19.7, 26.2, or $32.8 \mathrm{~mol} \cdot \mathrm{m}^{-2} \cdot \mathrm{d}^{-1}$ in the high $P P F$ treatment $\left(455 \mu \mathrm{mol} \cdot \mathrm{m}^{-2} \cdot \mathrm{s}^{-1}\right)$. Plants in all treatments received a 20 -hour photoperiod by providing $\approx 5 \mu \mathrm{mol} \cdot \mathrm{m}^{-2} \cdot \mathrm{s}^{-1}$ from incandescent lamps starting at the end of the photosynthetic light period. At low $P P F$, purslane grown under a 16 hour $P P F$ duration produced the highest concentrations of total fatty acids (TFA) and LNA per unit leaf dry weight (DW), but at high $P P F$, concentrations of these compounds were highest under 8 and 12 hour $P P F$ duration. Trend analysis indicated that maximum TFA and LNA concentrations occurred with a daily $P P F$ of 14.1 and $17.2 \mathrm{~mol} \cdot \mathrm{m}^{-2} \cdot \mathrm{d}^{-1}$, respectively; and in the thylakoids, protein, chlorophyll, and LNA concentrations peaked at a $P P F$ of 21.8 , 19.9 , and $16.1 \mathrm{~mol} \cdot \mathrm{m}^{-2} \cdot \mathrm{d}^{-1}$, respectively. LNA as a percentage of TFA was unaffected by treatment. Shoot DW increased with $P P F$ up to the highest PPF exposure of $32.8 \mathrm{~mol} \cdot \mathrm{m}^{-2} \cdot \mathrm{d}^{-1}$.
\end{abstract}

Recent interest in the dietary intake of omega-3 fatty acids $(\omega 3 \mathrm{FA})$ has been stimulated by a greater understanding of their role in normal human growth, development, and disease prevention (Simopoulos, 1991, 1999; Simopoulos et al., 1986). $\alpha$-Linolenic acid (LNA) is an W3FA that is essential in the human diet as a precursor for the synthesis of longer chain fatty acids and the prostaglandin group of mammalian hormones (British Nutrition Foundation, 1993).

Purslane (Portulaca oleracea) is an excellent dietary source of both LNA and the antioxidant, $\alpha$-tocopherol (Simopoulos et al., 1992), and because of this, there is renewed interest in the cultivation of purslane as a food crop (Adams, 1992; Levey, 1993). Although purslane has been studied in detail as a prolific weed (Vengris et al., 1972), very little is known about the effects of cultural conditions on its nutritional value (LNA content).

Lipid content and lipid metabolism in plants can be altered by a number of environmental factors including light and temperature (Harwood, 1995), mineral nutrient composition of the growing medium (Palaniswamy et al., 2000), and crop maturity (Hudson and Karis, 1974). Omara-Alwala et al. (1991) reported significant differences in the levels of total fatty acids (TFA) and W3FA in leaves and stems of purslane harvested at three different ages. Although these studies identified a few of the key environmental factors that may influence LNA concentrations in purslane leaves, many environmental conditions were not carefully controlled or monitored.

Several reports in the literature stress a close association between LNA and chlorophyll concentrations, suggesting a close positive relationship between LNA and chlorophyll synthesis. For instance, increased photosynthetic photon flux $(P P F)$ induced a correspond-

Received for publication 26 June 2000. Accepted for publication 7 May 2001 Storrs Agricultural Experiment Station scientific contribution 1947. This research was funded, in part by the University of Connecticut Research Foundation and the Storrs Agricultural Experiment Station. The cost of publishing this paper was defrayed in part by the payment of page charges. Under postal regulations, this paper therefore must be hereby marked advertisement solely to indicate this fact. ${ }^{1}$ Corresponding author; e-mail: palanisw@uconnvm.uconn.edu

${ }^{2}$ Department of Plant Science. ing increase in chlorophyll biosynthesis and LNA biosynthesis in Japanese morning glory (Pharbitis nil Choisy) (Tchang et al., 1985), pea (Pisum sativum L.) (Tremolieres, 1972; Tremolieres et al., 1973), and cotyledons of cucumber (Cucumis sativus L.) (Murphy and Stumpf, 1979). Tchang et al. (1985) described the rate of LNA synthesis in Japanese morning glory, as a "function of light and chlorophyll accumulation.” Anderson and Beardall (1991) declared a "synchronized synthesis of chlorophyll, fatty acids and proteins for the correct assembly of lipids and proteins" for the formation of uniform lamellar bilayers of the thylakoid membranes in plants. Therefore, the objectives of this study were to examine effects of total daily $P P F$ delivered under various combinations of irradiance and duration on growth, chlorophyll, and fatty acid concentrations, and to determine the environmental conditions that would maximize LNA in purslane leaves.

\section{Materials and Methods}

Plant material. Fourteen-day-old purslane seedlings (Valley Seed Service, Fresno, Calif.) were transplanted into $500-\mathrm{cm}^{3}$ square pots containing the commercial medium Metro 510 (O.M. Scotts, Marysville, Ohio), a mixture of sphagnum peat, vermiculite, and composted pine bark. Thirty-two pots were transferred to each of four growth chambers (model G-10; Environmental Growth Chambers, Chagrin Falls, Ohio), equipped with cool-white fluorescent/ incandescent light, programmed to maintain 12-h days/12-h nights of $27 / 22^{\circ} \mathrm{C}$.

Plant growth environment. Within each chamber, plants were arranged at two levels, so that 16 plants received an average instantaneous PPF (400 to $700 \mathrm{~nm}$ ) of $455 \mu \mathrm{mol} \cdot \mathrm{m}^{-2} \cdot \mathrm{s}^{-1}$, and the other 16 plants received an average $P P F$ of $299 \mu \mathrm{mol} \cdot \mathrm{m}^{-2} \cdot \mathrm{s}^{-1}$. Plants were grown under a $P P F$ of 299 or $455 \mu \mathrm{mol} \cdot \mathrm{m}^{-2} \cdot \mathrm{s}^{-1}$ for a daily duration of either $8,12,16$, or $20 \mathrm{~h}$. Total cumulative $P P F$ received by the plants per day was $8.6,12.9,17.2$, or $21.5 \mathrm{~mol} \cdot \mathrm{m}^{-2}$ for low $P P F\left(299 \mu \mathrm{mol} \cdot \mathrm{m}^{-2} \cdot \mathrm{s}^{-1}\right)$, and $13.1,19.7,26.2$, or $32.8 \mathrm{~mol} \cdot \mathrm{m}^{-2}$ for high $P P F\left(455 \mu \mathrm{mol} \cdot \mathrm{m}^{-2} \cdot \mathrm{s}^{-1}\right)$. The daily photoperiod was maintained at $20 \mathrm{~h}$ for all treatments by providing $\approx 5 \mu \mathrm{mol} \cdot \mathrm{m}^{-2} \cdot \mathrm{s}^{-1}$ from incandescent lamps starting at the end of the photosynthetic light 
period. Irradiance was measured at terminal leaf height using a quantum sensor (LI-190SA; LI-COR, Inc., Lincoln, Nebr.).

The $P P F$ in each growth chamber was greatest in the center row of the chamber and lower along the sides of the chamber. The gradient in the $299 \mu \mathrm{mol} \cdot \mathrm{m}^{-2} \cdot \mathrm{s}^{-1}$ treatments ranged from 318 $\mu \mathrm{mol} \cdot \mathrm{m}^{-2} \cdot \mathrm{s}^{-1}$ along the center of the chamber to $272 \mu \mathrm{mol} \cdot \mathrm{m}^{-2} \cdot \mathrm{s}^{-1}$ along the sides of the chamber. The gradient in the $455 \mu \mathrm{mol} \cdot \mathrm{m}^{-2} \cdot \mathrm{s}^{-1}$ treatments ranged from $463 \mu \mathrm{mol} \cdot \mathrm{m}^{-2} \cdot \mathrm{s}^{-1}$ along the center row to 441 $\mu \mathrm{mol} \cdot \mathrm{m}^{-2} \cdot \mathrm{s}^{-1}$ along the rear end of the chamber. To insure that all plants received similar $P P F$ during the study, the plants in each treatment were moved every day incrementally from the center of the chamber to the edges of the chamber in a continuous cycle across the light gradient. It took $16 \mathrm{~d}$ to complete one rotation. The $P P F$ values reported in this study were obtained by averaging the light measurements taken at various locations in the growth chamber every $5 \mathrm{~d}$ throughout the study period.

Treatments were arranged in a split-plot design with $P P F$ duration as the main plot and instantaneous $P P F$ as the subplot. The experiment was replicated in triplicate over time. Treatments were randomly assigned to chambers, resulting in a different chamber being used for each treatment each time the study was replicated. Plants were fertilized with $\mathrm{N}$ at $50 \mathrm{mg} \cdot \mathrm{mL}^{-1}$ for the first week and then twice weekly with $\mathrm{N}$ at $100 \mathrm{mg} \cdot \mathrm{mL}^{-1}$ until harvest using a $20 \mathrm{~N}$ 4.36P-16.6K water-soluble fertilizer (The Scotts Co., Marysville, Ohio).

As plants reached the 14-true-leaf stage, four plants were harvested from each treatment group and shoot fresh weight (FW), dry weight (DW), leaf area, and the number of lateral shoots arising from the main stem were determined. The shoot DW was determined after drying at $60^{\circ} \mathrm{C}$ for $24 \mathrm{~h}$. Leaf area was measured with a leaf area meter (LI 3100; LI-COR). At the same time, an additional eight plants were selected at random, and young, fully expanded leaves (leaves from the third, fourth and fifth nodes from the shoot tip), were harvested for chemical analysis. The harvested sample was divided into two subsamples. One subsample was used to determine thylakoid chlorophyll, fatty acids, and protein concentrations, and the other subsample was used to determine whole leaf chlorophyll concentration, and whole leaf fatty acid composition and concentrations.

ThylaKoID RECOVERY. Thylakoid membranes were recovered from leaf samples by grinding $\approx 4 \mathrm{~g}$ of leaf tissue in $20 \mathrm{~mL}$ of a 50 mM phosphate buffer ( $\mathrm{pH} 7.6$ ) containing $0.4 \mathrm{M}$ sorbitol, $20 \mathrm{~mm}$ $\mathrm{NaCl}, 20 \mathrm{~mm}$ HEPES, and $3 \mathrm{~mm} \mathrm{MgCl}_{2} \bullet 6 \mathrm{H}_{2} \mathrm{O}$ (Berkowitz and Gibbs, 1985; Chapman et al, 1983). The filtrate was centrifuged at $3000 g_{\mathrm{n}}$ for $4 \mathrm{~min}$, and the pellet was washed in $20 \mathrm{~mL}$ of a $50 \mathrm{~mm}$ phosphate buffer ( $\mathrm{pH} 7.6$ ) containing $20 \mathrm{~mm} \mathrm{NaCl}$, and shaken on ice for $15 \mathrm{~min}$. The thylakoid pellet was recovered following centrifugation at $10,000 g_{\mathrm{n}}$ for $10 \mathrm{~min}$.

Chlorophyll ANALYSIS. Thylakoid chlorophyll concentration was determined by suspending a $50-\mu \mathrm{L}$ sample of thylakoid membranes in $4 \mathrm{~mL}$ of $80 \%$ acetone and recording the absorbance at 645 $\mathrm{nm}$ and $663 \mathrm{~nm}$ (Arnon, 1949). Whole leaf chlorophyll was determined by extracting chlorophyll from leaf discs with N, N-dimethyl formamide and measuring absorption values at $647 \mathrm{~nm}$ and $664 \mathrm{~nm}$ (Inskeep and Bloom, 1985). The ratio of whole leaf chlorophyll to thylakoid chlorophyll was used to determine the percentage thylakoid recovery for each sample. The recovery factor was also used to estimate thylakoid protein on a leaf DW basis.

Protein analysis. Protein concentration was determined using the spectrophotometric procedure of Lowry et al. (1951). A 50- $\mu \mathrm{L}$ sample of thylakoid was suspended in $150 \mu \mathrm{L}$ of $0.85 \% \mathrm{NaCl}$ and $2.2 \mathrm{~mL}$ of Biuret reagent was added. After $30 \mathrm{~min}, 100 \mu \mathrm{L}$ of phenol reagent was added, mixed well, and the absorbance at $750 \mathrm{~nm}$ was recorded. Thylakoid protein was expressed as $\mathrm{mg} \cdot \mathrm{g}^{-1}$ leaf DW.

FAtTy ACID EXTRACTION, PREPARATION AND ANALYSES. Lipids were extracted using the dry column method (Maxwell et al., 1980). Leaf tissue $(\approx 4 \mathrm{~g})$ was homogenized for $30 \mathrm{~s}$ in $25 \mathrm{~mL} 9$ dichloromethane (DCM) : 1 methanol (v/v). The homogenate was mixed with $4 \mathrm{~g}$ anhydrous sodium sulfate and then flushed through a glass column $[22 \mathrm{~mm} \times 30 \mathrm{~cm}$ packed with 1 calcium phosphate : 9 celite $(\mathrm{w} / \mathrm{w})]$ with $150 \mathrm{mLDCM}$ : methanol $(9: 1, \mathrm{v} / \mathrm{v})$. The filtrate was collected and vacuum dried in a rotary evaporator. The dried lipid fraction was dissolved in $1 \mathrm{~mL} \mathrm{DCM}$ and transferred to 2-mL glass screw-cap vials, flushed with nitrogen, and stored under refrigeration until transesterfication.

The transesterfication procedure of Lepage and Roy (1986) was used to methylate the fatty acid fraction. A $100-\mu \mathrm{L}$ aliquot of extracted lipid was mixed with $2 \mathrm{~mL}$ of an internal standard [100 $\mu \mathrm{L} \cdot \mathrm{mL}^{-1}$ of heptadecanoic acid (a 17:0 fatty acid) in 4 methanol : 1 hexane $(\mathrm{v} / \mathrm{v})]$ and $200 \mu \mathrm{L}$ acetyl chloride in a screw cap test tube. Test tubes were sealed with Teflon thread seal tape and heated for $1 \mathrm{~h}$ at $100{ }^{\circ} \mathrm{C}$. After cooling, $5 \mathrm{~mL}$ of $6 \% \mathrm{~K}_{2} \mathrm{CO}_{3}$ was added slowly, mixed, and then centrifuged at $5000 g_{\mathrm{n}}$ for $10 \mathrm{~min}$. The lipid layer was removed, dried completely under nitrogen gas, and then dissolved in $50 \mu \mathrm{L} \mathrm{DCM}$. Finally, the resulting fatty acid methyl esters were injected into a gas chromatograph (Varian 6000, Palo Alto, Calif.) for fatty acid separation and analysis. Fatty acid peak areas were determined with a Hewlett Packard 3395 integrator (Wilmington, Del.) and identified by comparing retention times with standards separated under similar chromatographic conditions [poly unsaturated fatty acid (PUFA-2), Matreya, Inc., Pleasant Gap, Pa.].

Chromatographic conditions. The gas chromatograph was fitted with Supelcowax capillary column [10 stationary phase, $1 \mu \mathrm{m}$ film thickness, $0.53 \mathrm{~mm}$ i.d. $\times 30 \mathrm{~m}$ in length (Supelco, Bellefonte, $\mathrm{Pa}$.)] and a flame ionization detector. Air and hydrogen flow rates at the detector were maintained at 300 and $30 \mathrm{~mL} \cdot \mathrm{min}^{-1}$, respectively, and the nitrogen carrier gas flow rate was $1 \mathrm{~mL} \cdot \mathrm{min}^{-1}$. Column temperature gradient increased from 190 to $235^{\circ} \mathrm{C}$ at a rate of $2^{\circ} \mathrm{C} \cdot \mathrm{min}^{-1}$ and ion temperature was held at $240{ }^{\circ} \mathrm{C}$. Analysis time was $\approx 30 \mathrm{~min} /$ sample.

DATA ANALYSIS. Data were analyzed using SAS General Linear Models procedures (SAS Inst. Inc., 1994). Orthogonal polynomial contrasts were performed for significant responses and regression equations were generated.

Trendlines were fitted using Microsoft Power Point (7.0) software package and the Xmax for the significant responses (Y) were calculated as $\mathrm{Xmax}=-b / 2 c$, where $\mathrm{X}$ is the treatment, and $b$ and $c$ are the regression coefficients in the normal equation: $\mathrm{Y}=a+b \mathrm{X}+c \mathrm{X}^{2}$.

Transmission ELECTRON MICROSCOPY. Transverse sections of purslane leaves were prepared and examined under the electron microscope (Sims and Pearcy, 1992). Small pieces $(\approx 1 \mathrm{~mm})$ of fully expanded leaves were put in a fixative containing $8 \%$ glutaraldehyde and $10 \%$ formaldehyde and fixed by rotation on a rotating platform for $\approx 8 \mathrm{~h}$. The sections were then washed three times with distilled water and later three more times with $0.1 \mathrm{M}$ phosphate buffer to remove the fixatives. The samples were postfixed in osmium with $1 \%$ osmium in $0.1 \mathrm{~m}$ phosphate buffer, rotated for $2 \mathrm{~h}$ to remove the osmium and washed twice with distilled water. The sections were dehydrated in a graded ethanol series $(30 \%, 50 \%$, $70 \%, 95 \%$, and $100 \%$ ) and then twice in propylene oxide each at 0.5 $\mathrm{h}$ intervals. The dehydrated sections were fixed in resin (propylene oxide and resin, $1: 1$ ratio), left at $\approx 22^{\circ} \mathrm{C}$ for $\approx 8 \mathrm{~h}$, and later embedded in the resin mix and dried in the oven at $60{ }^{\circ} \mathrm{C}$ for 24 to $36 \mathrm{~h}$ in a 


\begin{tabular}{|c|c|c|}
\hline Regression equation & $r^{2}(P<0.05)$ & $\underline{x \max }$ \\
\hline$Y=-0.0645 x^{2}+1.8237 x+23.457$ & 0.54 & 14.1 TFA (O) \\
\hline$Y=-0.0782 x^{2}+4.1348 x-19.636$ & 0.91 & $26.4 \mathrm{FW}(\mathrm{O})$ \\
\hline
\end{tabular}
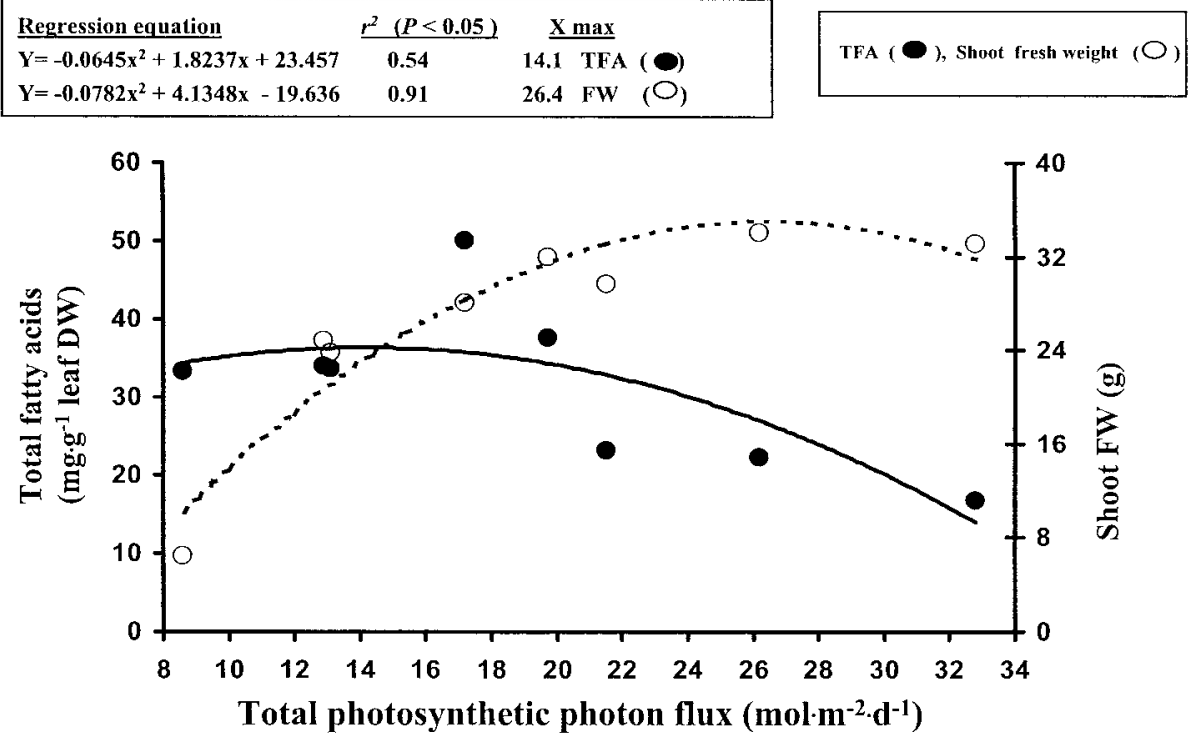

(18:2), and $62.9 \pm 2.2$ for linolenic (18:3).

Regression analysis showed that TFA (Y= $\left.-0.0645 \mathrm{x}^{2}+1.8237 \mathrm{x}+23.457 ; r^{2}=0.54\right)$ and LNA $\left(\mathrm{Y}=-0.0643 \mathrm{x}^{2}+2.2168 \mathrm{x}+2.8427 ; r^{2}=\right.$ $0.54)$ concentrations in purslane leaves peaked at a cumulative $P P F$ of 14.1 , and $17.2 \mathrm{~mol} \cdot \mathrm{m}^{-2} \cdot \mathrm{d}^{-1}$ respectively. However, maximum FW was recorded in plants receiving a $P P F$ of $26.4 \mathrm{~mol} \cdot \mathrm{m}^{-2} \cdot \mathrm{d}^{-1}$ (Fig. 1) and thylakoid protein, chlorophyll, and LNA concentrations were maximized at cumulative $P P F$ of 21.8 , 19.9 , and $16.1 \mathrm{~mol} \cdot \mathrm{m}^{-2} \cdot \mathrm{d}^{-1}$ respectively (calculated from data in Table 1).

At low irradiance $\left(299 \mu \mathrm{mol} \cdot \mathrm{m}^{-2} \cdot \mathrm{s}^{-1}\right)$, TFA and LNA concentrations in purslane leaves were $81 \%$ and $79 \%$ higher, respectively, at 16 $\mathrm{h} P P F$ duration $\left(17.2 \mathrm{~mol} \cdot \mathrm{m}^{-2} \cdot \mathrm{d}^{-1}\right)$ than at 20 h PPF $\left(21.5 \mathrm{~mol} \cdot \mathrm{m}^{-2} \cdot \mathrm{d}^{-1}\right)$ (Table 1). However at the high irradiance $\left(455 \mu \mathrm{mol} \cdot \mathrm{m}^{-2} \cdot \mathrm{s}^{-1}\right)$, the concentrations of TFA and LNA per unit leaf

Fig. 1. Changes in the total fatty acids concentration (TFA) and total shoot FW of purslane plants grown under different daily durations of $P P F$.

vacuum oven.

Thin sections were cut from the embedded leaf sections and mounted on copper grids [200 mesh $(0.127 \mathrm{~mm})]$ stained with lead citrate and examined under a transmission electron microscope (EM 300; Philips, Eindhoven, The Netherlands) at the University of Connecticut Electron Microscopy Laboratory.

\section{Results}

Relative concentration of individual fatty acid species, as a percentage by weight of TFA in purslane leaves were not influenced by total daily PPF. Mean fatty acid composition (all expressed as percentage of TFA $\pm \mathrm{SE}$ ) averaged across all light treatments was $16.3 \pm 1.0$ for palmitic (16:0), $2.7 \pm 0.2$ for palmitoleic $(16: 1), 1.2 \pm$ 0.1 for stearic (18:0), $3.9 \pm 0.4$ for oleic $(18: 1), 13 \pm 0.6$ for linoleic
DW decreased as $P P F$ duration increased from 12 to $20 \mathrm{~h}$. Similar concentrations of TFA and LNA (per unit leaf DW) were found in the leaves of purslane grown under 8 and $12 \mathrm{~h} P P F$ duration (13.1 and $\left.19.7 \mathrm{~mol} \cdot \mathrm{m}^{-2} \cdot \mathrm{d}^{-1}\right)$. Under a $16 \mathrm{~h} \mathrm{PPF} \mathrm{duration,} \mathrm{TFA} \mathrm{and} \mathrm{LNA}$ concentrations in purslane grown under the low irradiance were $124 \%$ and $136 \%$ higher, respectively, than in purslane grown under the high PPF (Table 1).

LNA concentrations in the thylakoid fraction recovered from plants in the various $P P F$ treatments followed the same pattern as observed for whole leaf TFA and LNA (Table 1). At low PPF, thylakoid LNA concentration increased as $P P F$ duration increased from 8 to $16 \mathrm{~h}$ and then decreased dramatically at $20 \mathrm{~h}$. At high $P P F$, thylakoid LNA concentration declined steadily as PPF duration increased from 8 to $20 \mathrm{~h}$.

Thylakoid protein concentrations followed a different pattern than thylakoid LNA in response to the various $P P F$ treatments (Table 1). At low PPF, thylakoid protein concentrations increased steadily as $P P F$ duration increased, from $261 \mathrm{mg} \cdot \mathrm{g}^{-1}$ leaf DW at 8

Table 1. Effect of total daily photosynthetic photon flux $\left(P P F, \mathrm{~mol} \cdot \mathrm{m}^{-2} \cdot \mathrm{d}^{-1}\right)$ on total fatty acids (TFA) and $\alpha$-linolenic acid (LNA) concentrations in leaves of purslane. Data represent means of three observations.

\begin{tabular}{|c|c|c|c|c|c|c|c|}
\hline \multicolumn{3}{|c|}{$P P F$ treatment } & \multirow{2}{*}{\multicolumn{2}{|c|}{ Whole-leaf concn }} & \multirow{2}{*}{\multicolumn{3}{|c|}{ Thylakoid concn }} \\
\hline$P P F$ & \multirow{3}{*}{$\begin{array}{c}\text { Instantaneous } \\
P P F \\
\left(\mu \mathrm{mol} \cdot \mathrm{m}^{-2} \cdot \mathrm{s}^{-1}\right) \\
\end{array}$} & \multirow{3}{*}{$\begin{array}{c}\text { Avg total } \\
P P F \\
\left(\mathrm{~mol} \cdot \mathrm{m}^{-2} \cdot \mathrm{d}^{-1}\right) \\
\end{array}$} & & & & & \\
\hline \multirow{2}{*}{$\begin{array}{l}\text { duration } \\
\text { (h) } \\
\end{array}$} & & & TFA & LNA & LNA & Protein & Chlorophyll \\
\hline & & & \multicolumn{2}{|c|}{$\left(\mathrm{mg} \cdot \mathrm{g}^{-1}\right.$ leaf DW $)$} & \multicolumn{3}{|c|}{$\left(\mathrm{mg} \cdot \mathrm{g}^{-1}\right.$ leaf DW $)$} \\
\hline \multirow[t]{2}{*}{8} & 299 & 8.6 & 33.2 & 15.1 & 2.2 & 261 & 16.6 \\
\hline & 455 & 13.1 & 33.7 & 21.7 & 10.6 & 303 & 16.2 \\
\hline \multirow[t]{2}{*}{12} & 299 & 12.9 & 34.0 & 19.2 & 11.8 & 295 & 20.3 \\
\hline & 455 & 19.7 & 37.6 & 23.9 & 5.6 & 471 & 20.7 \\
\hline \multirow[t]{2}{*}{16} & 299 & 17.2 & 50.0 & 32.3 & 12.1 & 344 & 21.7 \\
\hline & 455 & 26.2 & 22.3 & 13.7 & 3.5 & 532 & 21.9 \\
\hline \multirow[t]{2}{*}{20} & 299 & 21.5 & 23.1 & 15.2 & 3.5 & 555 & 21.4 \\
\hline & 455 & 32.5 & 16.8 & 10.6 & 1.5 & 217 & 12.5 \\
\hline \multicolumn{2}{|c|}{ Source of variation } & df & $\mathrm{F}$ value & $\mathrm{F}$ value & F value & $\mathrm{F}$ value & F value \\
\hline \multicolumn{2}{|c|}{$\overline{P P F}$ duration (h) } & 3 & $3.9^{\mathrm{NS}}$ & $29.9^{* * * *}$ & $18.6^{* *}$ & $7.6^{*}$ & $6.9^{*}$ \\
\hline \multicolumn{2}{|c|}{$P P F$ (irradiance) } & 1 & $9.4^{*}$ & $11.1^{*}$ & $3.6^{\mathrm{NS}}$ & $0.6^{\mathrm{NS}}$ & $3.9^{\mathrm{NS}}$ \\
\hline \multicolumn{2}{|c|}{ Total $P P F$ (duration $\times$ irradiance) } & 3 & $8.4^{*}$ & $22.3^{*}$ & $50.5^{* * *}$ & $14.8^{* *}$ & $4.0^{\mathrm{NS}}$ \\
\hline \multicolumn{2}{|l|}{$\mathrm{LSD}_{0.05}$} & & 13.1 & 10.0 & 6.9 & 226.0 & 4.2 \\
\hline
\end{tabular}

$\overline{\mathrm{Ns},{ }^{*}, * *, * * *}$ Nonsignificant or significant at $P \leq 0.05,0.01$, or 0.001 respectively. 
Table 2. Effect of photosynthetic photon flux $(P P F)$ on the relative ratio of thylakoid protein, chlorophyll, and $\alpha$-linolenic acid (LNA) and the ratio of thylakoid to whole leaf LNA in purslane. Data represent means of three observations.

\begin{tabular}{|c|c|c|c|c|c|c|}
\hline \multicolumn{3}{|c|}{$P P F$ treatment } & \multirow{2}{*}{\multicolumn{3}{|c|}{ Ratios in thylakoid }} & \multirow{3}{*}{$\begin{array}{l}\text { Ratio of } \\
\text { thylakoid LNA } \\
\text { to total LNA }\end{array}$} \\
\hline \multirow{2}{*}{$\begin{array}{l}P P F \\
\text { duration } \\
\text { (h) }\end{array}$} & \multirow{2}{*}{$\begin{array}{c}\text { Instantaneous } \\
P P F \\
\left(\mu \mathrm{mol} \cdot \mathrm{m}^{-2} \cdot \mathrm{s}^{-1}\right)\end{array}$} & \multirow{2}{*}{$\begin{array}{c}\text { Avg total } \\
P P F \\
\left(\mathrm{~mol} \cdot \mathrm{m}^{-2} \cdot \mathrm{d}^{-1}\right)\end{array}$} & & & & \\
\hline & & & $\begin{array}{l}\text { LNA: } \\
\text { protein }\end{array}$ & $\begin{array}{c}\text { LNA: } \\
\text { chlorophyll }\end{array}$ & $\begin{array}{l}\text { Protein: } \\
\text { chlorophyll }\end{array}$ & \\
\hline \multirow[t]{2}{*}{8} & 299 & 8.6 & 8.5 & 132 & 15.8 & 146 \\
\hline & 455 & 13.1 & 36.6 & 663 & 19.1 & 488 \\
\hline \multirow[t]{2}{*}{12} & 299 & 12.9 & 41.8 & 586 & 14.6 & 615 \\
\hline & 455 & 19.7 & 12.6 & 265 & 22.2 & 234 \\
\hline \multirow[t]{2}{*}{16} & 299 & 17.2 & 38.1 & 551 & 15.5 & 375 \\
\hline & 455 & 26.2 & 6.8 & 162 & 24.6 & 255 \\
\hline \multirow[t]{2}{*}{20} & 299 & 21.5 & 6.9 & 162 & 25.7 & 230 \\
\hline & 455 & 32.5 & 6.8 & 116 & 16.9 & 142 \\
\hline \multicolumn{2}{|c|}{ Source of variation } & df & F value & F value & F value & $\mathrm{F}$ value \\
\hline \multicolumn{2}{|c|}{$\overline{P P F}$ duration (h) } & 3 & $27.3^{* * * *}$ & $18.6^{* *}$ & $14.5^{*}$ & $7.7^{* *}$ \\
\hline \multicolumn{2}{|c|}{$P P F$ (irradiance) } & 1 & $10.7 *$ & $3.6^{\mathrm{NS}}$ & $4.5^{\mathrm{NS}}$ & $2.4^{\mathrm{NS}}$ \\
\hline \multicolumn{2}{|c|}{ Total $P P F$ (duration $\times$ irradiance) } & 3 & $31.8^{* * * *}$ & $50.5^{* * *}$ & $9.5^{*}$ & $11.0^{* *}$ \\
\hline \multicolumn{2}{|l|}{$\mathrm{LSD}_{0.05}$} & & 25.8 & 385.0 & 7.4 & 206.0 \\
\hline
\end{tabular}
$\mathrm{Ns}^{*},{ }^{* * * * * * *}$ Nonsignificant or significant at $P \leq 0.05,0.01$, or 0.001 respectively.

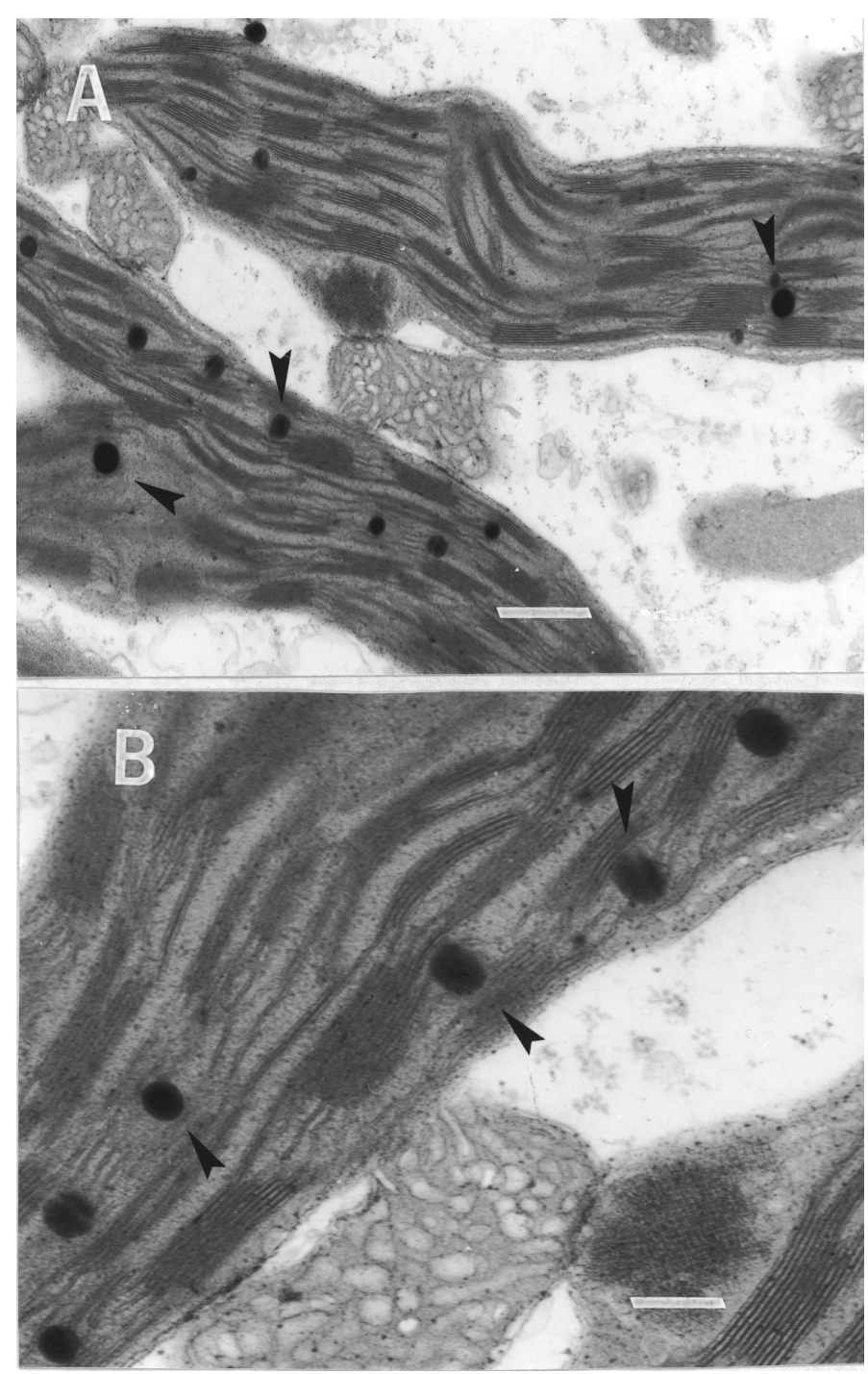

$\mathrm{h}$ to $555 \mathrm{mg} \cdot \mathrm{g}^{-1}$ leaf DW at $20 \mathrm{~h}$. At high $P P F$, thylakoid protein concentrations increased as $P P F$ duration increased from 8 to 16 $\mathrm{h}$, and then declined dramatically at $20 \mathrm{~h}$.

Thylakoid LNA concentration per unit thylakoid protein was affected by total $P P F$ (Table 2). At low $P P F$ irradiance, the ratio of thylakoid LNA to protein increased over 4.5-fold when $P P F$ duration increased from $8 \mathrm{~h}$ to $12 \mathrm{~h}$ or $16 \mathrm{~h}$. At $20 \mathrm{~h} P P F$ duration, thylakoid LNA to protein ratio was similar to that observed at 8 h. However, at high $P P F$ irradiance the thylakoid LNA to protein ratio decreased over $65 \%$ when $P P F$ duration increased from $8 \mathrm{~h}$ to $12 \mathrm{~h}$, and decreased an additional $46 \%$ when $P P F$ duration increased from $12 \mathrm{~h}$ to either $16 \mathrm{~h}$ or $20 \mathrm{~h}$. Changes in the thylakoid LNA to thylakoid chlorophyll ratio in response to the various $P P F$ treatments were similar to those observed for the thylakoid LNA to protein ratio (Table 2).

In contrast, the ratio of thylakoid protein to thylakoid chlorophyll in leaves exposed to low $P P F$ irradiance was unchanged as $P P F$ duration increased from 8 to $16 \mathrm{~h}$, and then increased at 20 h $P P F$ duration (Table 2). The ratio of thylakoid protein to thylakoid chlorophyll in purslane leaves exposed to the high $P P F$ irradiance increased gradually as the $P P F$ duration increased from 8 to $16 \mathrm{~h}$, and then decreased at $20 \mathrm{~h} P P F$ duration. Thylakoid chlorophyll concentration was lowest at the average $P P F$ of $32.5 \mathrm{~mol} \cdot \mathrm{m}^{-2} \cdot \mathrm{d}^{-1}$ (Table 1 ).

LNA recovered in the thylakoid fraction relative to the total LNA in the whole leaf varied dramatically with $P P F$ treatment (Table 2). At the low PPF irradiance, LNA recovered in the thylakoid fraction increased from $14.6 \%$ of the total whole leaf LNA at the $8 \mathrm{~h} P P F$ duration to $61.5 \%$ of the total at the $12 \mathrm{~h} P P F$ duration, and then declined steadily to $23 \%$ at the $20 \mathrm{~h} P P F$ duration. At the high $P P F$ irradiance, LNA in the thylakoid accounted for over $48 \%$ of the total whole leaf LNA when plants were grown at an $8 \mathrm{~h} P P F$ duration, but then declined at longer

Fig. 2. Transmission electron micrographs of purslane chloroplast, illustrating osmiophilic lipid globules embedded in thylakoid membranes of leaves of plants grown at (A) total cumulative $P P F$ of $8.6 \mathrm{~mol} \cdot \mathrm{m}^{-2} \cdot \mathrm{d}^{-1}\left(299 \mu \mathrm{mol} \cdot \mathrm{m}^{-2} \cdot \mathrm{s}^{-1}\right.$ for a daily duration of $8 \mathrm{~h})$ and $(\mathbf{B})$ total cumulative $P P F$ of $21.5 \mathrm{~mol} \cdot \mathrm{m}^{-2} \cdot \mathrm{d}^{-1}\left(299 \mu \mathrm{mol} \cdot \mathrm{m}^{-2} \cdot \mathrm{s}^{-1}\right.$ for a daily duration of $20 \mathrm{~h}$ ). Scale bars $=1.4 \mu \mathrm{m}$. The arrows point to the osmiophilic lipid globules. 
Table 3. Effect of total daily photosynthetic photon flux $\left(P P F, \mathrm{~mol} \cdot \mathrm{m}^{-2} \cdot \mathrm{d}^{-1}\right)$ on growth of purslane. Data represent means of three observations

\begin{tabular}{|c|c|c|c|c|c|c|c|}
\hline \multirow{3}{*}{$\begin{array}{l}P P F \\
\text { duration } \\
\text { (h) }\end{array}$} & \multicolumn{2}{|l|}{$P P F$ treatment } & & & & & \\
\hline & Instantaneous & Avg total & \multicolumn{5}{|c|}{ Growth parameter } \\
\hline & $\begin{array}{c}P P F \\
\left(\mu \mathrm{mol} \cdot \mathrm{m}^{-2} \cdot \mathrm{s}^{-1}\right)\end{array}$ & $\begin{array}{c}P P F \\
\left(\mathrm{~mol} \cdot \mathrm{m}^{-2} \cdot \mathrm{d}^{-1}\right)\end{array}$ & $\begin{array}{l}\text { Leaf DW } \\
(\mathrm{g})\end{array}$ & $\begin{array}{l}\text { Shoot DW } \\
(\mathrm{g})\end{array}$ & $\begin{array}{l}\text { Leaf area } \\
\left(\mathrm{cm}^{2}\right)\end{array}$ & $\begin{array}{c}\text { Shoot } \\
\text { no. }\end{array}$ & $\begin{array}{l}\text { Plant ht } \\
(\mathrm{cm})\end{array}$ \\
\hline \multirow[t]{2}{*}{$\overline{8}$} & 299 & 8.6 & 0.11 & 0.3 & 72 & 0.9 & 24.7 \\
\hline & 455 & 13.1 & 0.39 & 0.9 & 145 & 2.5 & 31.5 \\
\hline \multirow[t]{2}{*}{12} & 299 & 12.9 & 0.46 & 1.1 & 141 & 2.5 & 30.1 \\
\hline & 455 & 19.7 & 0.69 & 1.6 & 263 & 3.0 & 35.7 \\
\hline \multirow[t]{2}{*}{16} & 299 & 17.2 & 0.54 & 1.3 & 213 & 3.1 & 36.6 \\
\hline & 455 & 26.2 & 0.86 & 1.7 & 293 & 3.3 & 34.8 \\
\hline \multirow[t]{2}{*}{20} & 299 & 21.5 & 0.64 & 1.3 & 228 & 3.3 & 27.0 \\
\hline & 455 & 32.5 & 1.0 & 1.9 & 270 & 3.1 & 27.8 \\
\hline \multicolumn{2}{|c|}{ Source of variation } & df & F value & F value & F value & F value & F value \\
\hline \multicolumn{2}{|c|}{$\overline{P P F}$ duration (h) } & 3 & $111.6^{* * *}$ & $106.2^{* * * *}$ & $26.8^{* * * *}$ & $166.1^{* * * *}$ & $17.7^{* *}$ \\
\hline \multicolumn{2}{|c|}{$P P F$ (irradiance) } & 1 & $79.9^{* * * *}$ & $37.8^{* * * *}$ & $30.1^{* * * *}$ & $29.6^{* * * *}$ & $10.7^{* *}$ \\
\hline \multicolumn{2}{|c|}{ Total $P P F(\mathrm{~h} \times$ irradiance $)$} & 3 & $0.9^{\mathrm{NS}}$ & $0.2^{\mathrm{NS}}$ & $1.3^{\mathrm{NS}}$ & $16.2^{* * * *}$ & $5.5^{*}$ \\
\hline \multicolumn{2}{|l|}{$\mathrm{LSD}_{0.05}$} & & 6.2 & 0.3 & 50.2 & 0.7 & 3.8 \\
\hline
\end{tabular}

NS,***,**** Nonsignificant or significant at $P \leq 0.05,0.01$, or 0.001 respectively.

$P P F$ duration to a low of $14.2 \%$ in purslane grown under a $20 \mathrm{~h}$ $P P F$ duration. Micrographic analysis of purslane leaf sections revealed the presence of numerous osmiophilic lipid globules inside the large chloroplasts (Fig. 2).

While the relationship between total $P P F$ and TFA concentration is complex (Fig. 1), the relationship between plant growth and total $P P F$ is clear (Table 3). Purslane shoot DW, leaf DW, and leaf area all increased with increased total $P P F$ (Table 3). At both low and high $P P F$ irradiance, plant growth (as represented by leaf $\mathrm{DW}$, shoot DW, and total leaf area) increased with increased $P P F$ duration.

Plant growth habit was influenced greatly by the interplay between $P P F$ duration and irradiance. The number of lateral shoots that developed on each plant increased $\approx 2.5$ to 3.5 -fold when $P P F$ duration increased from $8 \mathrm{~h}$ to 12 or more hours at the low $P P F$ irradiance (Table 3). However, at the high $P P F$ irradiance the number of lateral shoots varied little with $P P F$ duration from a minimum of 2.5 shoots/plant under the $8 \mathrm{~h} P P F$ duration to a maximum of $3.5 /$ plant under the $16 \mathrm{~h} P P F$ duration. At the low $P P F$ irradiance, plant height increased with increased $P P F$ duration up to $16 \mathrm{~h}$, but then decreased at $20 \mathrm{~h} P P F$ duration. At the high $P P F$ irradiance, plant height increased only slightly as $P P F$ duration increased from $8 \mathrm{~h}$ to $12 \mathrm{~h}$ and then decreased at the 20 h $P P F$ duration.

\section{Discussion}

Total $P P F$ exerted a strong influence over fatty acid concentrations in purslane leaves, but did not alter LNA as a percentage of TFA. Though TFA and LNA concentrations were altered by the $P P F$ treatments, LNA as a percentage of TFA remained the same in all the treatments (Table 1). Burkey et al. (1997) reported that in soybean [Glycine $\max (\mathrm{L}$.) Merrill] leaves maintained relatively constant ratios of fatty acids under various light exposures.

The relationship between $P P F$ and whole-leaf TFA, and between PPF and thylakoid protein, is complex in that the response to $P P F$ irradiance appears to be dependent on $P P F$ duration. Wholeleaf TFA concentration reached a maximum at a cumulative daily $P P F$ of $14.1 \mathrm{~mol} \cdot \mathrm{m}^{-2} \cdot \mathrm{d}^{-1}$, which was attained after $8.6 \mathrm{~h}$ at high $P P F$ and 13.1 hat low $P P F$ and then decreased at higher cumulative $P P F \mathrm{~s}$
(Fig. 1). A similar trend was also observed for LNA(Table 1). Thus, fatty acid concentrations in purslane leaves were determined by the total daily $P P F$ exposure rather than by irradiance or duration.

In contrast, chlorophyll concentration increased linearly with increased $P P F$ duration regardless of $P P F$ irradiance (Table 3). Chlorophyll concentration increased as $P P F$ increased to $\approx 20$ $\mathrm{mol} \cdot \mathrm{m}^{-2} \cdot \mathrm{d}^{-1}$, and then decreased (Table 1 ). Total LNA concentration peaked at a lower $P P F$ than did chlorophyll and then declined at a more rapid rate than chlorophyll at high daily $P P F$.

Thylakoid protein, chlorophyll, and LNA concentrations are influenced by cumulative daily $P P F\left(\mathrm{~mol} \cdot \mathrm{m}^{-2} \cdot \mathrm{d}^{-1}\right)$ received by the plant, but regression analysis showed they peaked at a different total $P P F$. Protein and chlorophyll accumulations were maximized at a higher total $P P F\left(21.8\right.$ and $19.9 \mathrm{~mol} \cdot \mathrm{m}^{-2} \cdot \mathrm{d}^{-1}$, respectively) than was thylakoid LNA $\left(16.1 \mathrm{~mol} \cdot \mathrm{m}^{-2} \cdot \mathrm{d}^{-1}\right)$ or total leaf LNA $\left(17.2 \mathrm{~mol} \cdot \mathrm{m}^{-2} \cdot \mathrm{d}^{-1}\right)$. These results indicate that LNA accumulation in purslane was not necessarily linked to chlorophyll (Palaniswamy et al., 2000) or protein concentration as observed earlier in other plants (Melis, 1984; Murphy and Stumpf, 1979; Tchang et al., 1985; Tremolieres, 1972; Tremolieres et al., 1973, 1979).

LNA : chlorophyll in leaves was highest in the thylakoid fraction extracted from plants grown under high $P P F$ for $8 \mathrm{~h}$ followed by those grown under low $P P F$ for 12 to $16 \mathrm{~h}$ (Table 2 ). A similar trend was also seen in the LNA : protein ratio in the leaves. Chapman et al. (1983) observed higher lipid to chlorophyll ratio in leaves of pea grown under winter conditions (normally associated with shorter photosynthetic light periods and lower irradiances). Chapman et al. (1982) hypthothesized that chlorophyll levels are a reflection of protein content, but in our study changes in chlorophyll concentration did not coincide directly with changes in protein concentration (Table 1). Unlike pea, purslane is a $\mathrm{C}_{4}$ plant that exhibits crassulacean acid metabolism under short photoperiod or water stress conditions commonly associated with a high light environment (Koch and Kennedy, 1980).

Though Anderson and Beardall (1991) reported that there is "synchronized synthesis of chlorophyll, LNA and proteins" to enable the correct assembly of lipids and proteins leading to the formation of uniform lamellar bilayers of the thylakoid membranes in plants, our results indicate that synthesis of each of these membrane components in purslane may be influenced differently by $P P F$ 
irradiance and duration, reflecting the different roles these compounds play in plant metabolism.

Barta (1975) observed that lipid synthesis was related positively to the rate of photosynthesis and DW accumulation. With purslane, DW accumulation continued to increase with higher $P P F$ and longer durations, and LNA accumulation did not. Since chlorophyll, protein, and LNA synthesis are influenced differently by the instantaneous $P P F, P P F$ duration, and the cumulative daily $P P F$, it is evident that LNA synthesis/accumulation in purslane leaves was not directly linked to the DW accumulation as suggested by Barta (1975). Simopoulos et al. (1992) reported that purslane grown in growth chambers at an $18 \mathrm{~h}$ photoperiod, with a $P P F$ of $200 \mu \mathrm{mol} \cdot \mathrm{m}^{-2} \cdot \mathrm{s}^{-1}$, and days/nights of $24 / 17^{\circ} \mathrm{C}$, were richer in $\omega 3 \mathrm{FA}$ than were plants grown in the summer at Beltsville, Md., under field conditions.

In soybean leaves, Burkey et al. (1997) observed a shift in carbon metabolism toward the storage lipids at low irradiance. They suggested that the shift occurred because export of photosynthates from the leaves was either prohibited or the demand for photosynthates by sink tissues was limited. Extra-thylakoidal LNA (the portion of total LNA not associated with the thylakoid membrane) tended to increase as thylakoid LNA decreased and decreased as thylakoid LNA increased. Conditions that reduce photosynthesis such as water stress can cause a decline in carbon export from soybean leaves (Huber et al., 1984), and increase storage lipids in cotton (Gossypium hirsutum L.) leaves (Wilson et al., 1987) and maize (Zea mays L.) leaves (Douglas and Paleg, 1981).

Based on our data one can speculate that purslane plants invest more carbon in the synthesis of chloroplasts under conditions that favor $\mathrm{C}_{4}$ metabolism rather than crassulacean acid metabolism. In addition, at very high $P P F$ excess light may cause photoinhibition or damage to the photosynthetic apparatus requiring a high percentage of stored fatty acids for repair purposes. Thus, even though TFA and LNA were relatively low under the highest PPF treatments, the percentage of extra-thylakoidal LNA was very high. In contrast, at moderate light levels $\left(\approx 13 \mathrm{~mol} \cdot \mathrm{m}^{-2} \cdot \mathrm{d}^{-1}\right)$ TFA and LNA concentrations were very high, but the percentage of stored LNA was relatively low.

Most LNA in higher plants is associated with the chloroplasts. In addition LNA is the major constituent of the thylakoid membrane (Tremolieres, et al., 1979)-69\% in spinach (Spinacea oleracea L.) (Allen et al., 1966), 65\% in wheat (Triticum aestivum L.) (Wolff, 1966), and $72 \%$ in broad bean (Vicia faba L.) (Crombie, 1958). However, the percentage of total leaf LNA associated with purslane thylakoid membranes in our study varied dramatically with total daily $P P F$.

Simopoulos and Salem Jr. (1986) observed that LNA concentration of purslane was about six times higher than in spinach, but chlorophyll concentration was lower than that of spinach [average chlorophyll concentration of spinach was $44.7 \mathrm{mg} \cdot \mathrm{cm}^{-2}$, and that of purslane was $37.7 \mathrm{mg} \cdot \mathrm{cm}^{-2}$ (personal observations)].

Results herein indicate that LNA/protein and LNA/chlorophyll ratios were altered by the various treatment conditions without changing the relative proportions of the lipid species (Table 2). Perhaps this provided an adaptive mechanism to maintain the optimal fluidity of the thylakoids, and negating the need for change in the fatty acid saturation levels or the relative proportions of the lipid classes (Hiller and Raison, 1980). Our data also indicate that $P P F$ can be manipulated by supplemental lighting in winter and shading during summer to improve the nutritional value (LNA content) of greenhouse-grown purslane.

\section{Literature Cited}

Adams, S. 1992. Purslane eyed as rich food source. Agr. Res. Ag Notes. USDA. 40(12):20.

Allen, C.F., O. Hirayama, and P. Good. 1966. Lipid composition of photosynthetic systems, p. 195-200. In: T.W. Goodwin (ed.). Biochemistry of chloroplasts. vol. 1. Academic Press, New York.

Anderson, J.W. and J. Beardall. 1991. Structural organization of plant cells, p. 36-49. In: J.W. Anderson, and J. Beardall (ed.). Molecular activities of plant cells: An introduction to plant biochemistry. Blackwell Scientific Publications, Cambridge, Mass.

Arnon, D.I. 1949. Copper enzymes in chloroplasts: Polyphenoloxidases in Beta vulgaris. Plant Physiol. 24:1-14.

Barta, A.L. 1975. Higher fatty acid content of perennial grasses as affected by species and by nitrogen and potassium fertilization. Crop Sci. 15:169190.

Berkowitz, G.A. and M. Gibbs. 1985. Chloroplasts as a whole, p. 153-181. In: H.F. Linskens and J.F Jackson (eds.). Modern methods of plant analysis. New series. vol. 1. Cell components. Springer-Verlag, Berlin. British Nutrition Foundation. 1993. Unsaturated fatty acids: Nutritional and physiological significance. Rpt. of the British Nutrition Foundation's task force. Chapman and Hall, London.

Burkey, K.O., R.F. Wilson, and R. Wells. 1997. Effects of canopy shade on the lipid composition of soybean leaves. Physiol. Plant. 101:591-598.

Chapman, D.J., J. De-Felice, and J. Barber. 1983. Influence of winter and summer growth conditions on leaf membrane lipids of Pisum sativum $\mathrm{L}$. Planta 157:218-223.

Chapman, D.J., P.A. Millner, R.C. Ford, and J. Barber. 1982. Lipid content of chloroplast thylakoids and regulation of photosynthetic electronic transport, p. 363-368. In: J.F.G.M. Wintermans and P.J.C. Kuiper (eds.). Biochemistry and metabolism of plant lipids. Elsevier, North-Holland, Amsterdam.

Crombie, W.M. 1958. Fatty acids in chloroplasts and leaves. J. Expt. Bot. 9:254-261.

Douglas, T.J. and L.G. Paleg. 1981. Lipid composition of Zea mays seedlings and water-stressed changes. J. Expt. Bot. 32:499-508.

Harwood, J.L. 1995. Recent environmental concerns and lipid metabolism, p. 361-368. In: J.C. Kader and P. Mazliak (eds.). Plant lipid metabolism, Kluwer Academic Publishers, Dordrecht, The Netherlands.

Hiller, R.G. and J.K. Raison. 1980. The fluidity of chloroplast thylakoid membranes and their constituent lipids: A comparative study by ESR. Biochim. Biophys. Acta. 599:63-72.

Huber, S.C., H.H. Rogers, and F.L. Mowry. 1984. Effects of water stress on photosynthesis and carbon partitioning on soybean [Glycine max (L.) Merr.] plants grown in the field at different $\mathrm{CO}_{2}$ levels. Plant Physiol. 76:244-249.

Hudson, J.F. and I.G. Karis. 1974. Effect of crop maturity on leaf lipids. J. Sci. Food. Agr. 25:1491-1502.

Inskeep, W.P. and P.R Bloom. 1985. Extinction coefficients of chlorophyll a and $\mathrm{b}$ in $\mathrm{N}, \mathrm{N}$-dimethylformamide and $80 \%$ acetone. Plant Physiol. 60:606-608.

Koch, K. and R.A. Kennedy. 1980. Characteristics of crassulacean acid metabolism in the succulent $\mathrm{C}_{4}$ dicot, Portulaca oleracea L. Plant Physiol. 65:193-197.

Lepage, G. and C.C. Roy. 1986. Direct esterification of all classes of lipids in a one step reaction. J. Lipid Res. 27:114-120.

Levey, G.A. 1993. The new power foods. Parade magazine. The Washington Post, 14 Nov. 1993. p. 5.

Lowry, O.H., N.J. Rossenbrough, A.L. Farr, and R.J. Randall. 1951. Protein measurement with the folin phenol reagent. J. Biol. Chem. 193:265-275.

Maxwell, R.J., W.N. Marmer, M.P. Zubillage, and G.A. Dalickas. 1980. Determination of total fat in meat and meat products by a rapid, dry column method. J. Assn. Offic. Anal. Chem. 63:600-603.

Melis, A. 1984. Light regulation of photosynthetic membrane structure, organization, and function. J. Cell. Biochem. 24:271-285.

Murphy, D.J. and P.K. Stumpf. 1979. Light dependent induction of polyunsaturated fatty acid biosynthesis in greening cucumber cotyledons. Plant Physiol. 63:328-335. 
Omara-Alwala, T.R., T. Mebrahtu, D.E. Prior, and M.O. Ezekwe. 1991. Omega-three fatty acids in purslane (Portulaca oleracea) tissues. J. Assn. Offic. Anal. Chem. 68:198-199.

Palaniswamy U.R., R.J. McAvoy, and B. Bible. 2000. Omega-3-fatty acid concentration in Portulaca oleracea L. is altered by nitrogen source in hydroponic solution. J. Amer. Soc. Hort. Sci. 125:190-194.

SAS Institute, Inc. 1994. SAS user's guide: Statistics. Version 6. $4^{\text {th }}$ ed. SAS Inst., Cary, N.C.

Simopoulos, A.P. 1991. Omega-3 fatty acids in health and disease and in growth and development. Amer. J. Clin. Nutr. 54:438-463.

Simopoulos, A.P. 1999. Essential fatty acids in health and chronic disease. Amer. J. Clin. Nutr. 70(3 Suppl.):560S-569S.

Simopoulos, A.P, R.E. Kifer, and R.R. Martin. 1986. Health effects of polyunsaturated fatty acids in seafoods. Proc. Conf. on the Health Effects of Polyunsaturated Fatty Acids in Seafoods. June 1985. Academic Press, Orlando, Fla.

Simopoulos, A.P., H.A. Norman, J.E. Gillapsy, and J.A Duke. 1992. Common purslane: A source of omega-3 fatty acids and antioxidants. J. Amer. Col. Nutr. 11:374-382.

Simopoulos, A.P. and N. Salem, Jr. 1986. Purslane: A terrestrial source of omega-3 fatty acids. New England J. Med. 315:833.

Sims, D.A. and R.W. Pearcy. 1992. Response of leaf anatomy and photosynthetic capacity in Alocasia macrorrizha (Araceae) to a transfer from low to high light. Amer. J. Bot. 79: 449-455.

Tchang, F., A. Connan, D. Robert, and A. Tremolieres. 1985. Effects of light and temperature on $\alpha$-linolenic acid biosynthesis in developing cotyledons of Pharbitis nil. Physiol. Veg. 23:361-371.

Tremolieres, A. 1972. Biosynthese de l'acide linolenique dans la feuille de pois. Phytochemistry 11:3453-3460.

Tremolieres, A., T. Guillot-Salomon, J.P. Dubacq, R. Jacques, P. Mazliak, and M. Signol. 1979. The effect of monochromatic lights on linolenic and trans-3 hexadecenoic acid biosynthesis and its correlation to development of the plastid lamellar system. Physiol. Plant. 45:429-436.

Tremolieres, A., R. Jacques, and P. Mazliak. 1973. Regulation par la lumiere de l'accumulation de l'acide linolenique dans la jeune feuille de Pois. Spectre d'action, influence de l'intensite' de l'eclairement. Physiol. Veg. 11:239-251.

Vengris, J., S. Dunn, and M.S. Sapunckis. 1972. Life history studies as related to weed control in the northeast. 7. Common purslane. Res. Bul. 598:1-45. Northeast Reg. Publ., Univ. of Mass., Amherst.

Wilson, R.F., J.J. Burke, and J.E. Quisenberry. 1987. Plant morphological and biochemical responses to field water deficits. II. Responses of leaf glycerolipid composition in cotton. Plant Physiol. 84:251-254.

Wolff, I.A. 1966. Seed lipids. Science 154:1140-1149. 